\title{
GRP Gene Product
}

National Cancer Institute

\section{Source}

National Cancer Institute. GRP Gene Product. NCI Thesaurus. Code C113249.

A protein encoded by the GRP gene. 